\title{
INCREASING KNOWLEDGE OF PREGNANT MOTHERS ABOUT IUD CONTRACEPTION METHODS ON THE USE OF KOPIKU APPLICATION
}

\author{
Meti Patimah, Tatu Septiani Nurhikmah, Noorhayati Novayanti, Ratni $\mathbf{N}_{\text {, }}$ \\ Adila Fitria, Ihat Sholihat, Prilly Indah Gunawan, Sri Ayu Jaoza
}

\author{
${ }^{1}$ Program Studi D3 Kebidanan, Universitas Muhammadiyah Tasikmalaya \\ (meti.patimah@umtas.ac.id, 082112233033)
}

\begin{abstract}
Problems related to the stagnation of the family planning program in Indonesia are thought to be caused by the level of contraceptive use and unmet need for family planning, a decrease in fertility or fertility rates, an increase in the proportion of early marriage, limited knowledge of reproductive health, and sexual activity outside of marriage which leads to Total Maternal Mortality Rate (MMR). The purpose of this activity is to implement the "KOPIKu" application. This community partnership service is carried out in Cilamajang Village. Kawalu District, Tasikmalaya City, which is the working area of the Karanganyar Community Health Center for 35 primigravida III trimester pregnant women. This activity is an application of the "KOPIKu" My Choice of Contraception which is installed on a smartphone. The results show that the knowledge of mothers before using the KOPIKu application was mostly in the less category at $85.7 \%$, while the mother's knowledge after using the "KOPIKu aplikasi application was mostly in the good category at $82.9 \%$.
\end{abstract}

Keyword : Apliction, IUD, KOPIKu, Knowledge

\section{INTRODUCTION}

Indonesia is a developing country with high population growth, the average birth rate (TFR) in 2018 was 2.45, which was greater than the national target that had to be met as much as 2.28 with a total PUS of 36.8 million. (BKKBN, 2019 ). The family planning program which has been launched since 1970 has not been able to solve the population problem. Problems related to the stagnation of the family planning program in Indonesia are suspected to be caused by the level of contraceptive use and unmet need for family planning, a decrease in fertility rates, an increase in the proportion of early marriages, limited knowledge about reproductive health, and sexual activity outside marriage which leads to Total Maternal Mortality Rate (MMR). Referring to the Sustainable Development Goals (SDG's) formulated by the World Health Organization (WHO), that maternal and child health is the main concern in creating a generation that has quality and has a good degree of health. This goal is actually in line with the national family planning program that is being carried out. Family planning is not a concept to eliminate births but a planning concept to produce a family as a generation with quality health degrees. (FKUI, 2019)

Increased knowledge and decision making with counseling between clients and officers using the Family Planning Decision Making Tool (ABPK KB). ABPK is a tool that 
has a dual function, which is used by providers as a work tool to make decisions on family planning methods, help solve problems in the use of family planning, provide references and visual aids for training new providers. Indonesian Health, 2008) However, this tool has a weakness, its large size and weight make it difficult for providers to carry it. The purpose of this activity is to increase the knowledge of pregnant women about the IUD contraceptive method, so that they want to use the IUD after delivery.

\section{MATERIALS AND METHODS}

Community partnership service is carried out in Cilamajang Village. Kawalu District, Tasikmalaya City, which is the working area of the Karanganyar Health Center. The population in this service is women of childbearing age, while the sample is primigravida third trimester pregnant women as many as 35 people with a sampling technique using total sampling.

This activity is an application of the KOPIKu" My Preferred Contraception application which is installed on a smartphone. Previously, pregnant women were given a questionnaire to measure the knowledge of pregnant women about the IUD contraceptive method, and were given the questionnaire again after 1 week of using the application.

\section{RESULT}

This activity obtained the result that the knowledge of mothers before health education was the most in the less category by $85.7 \%$ while the knowledge of mothers after being given health education with the KOPIKu" application was the most in the good category at $82.9 \%$.

\section{DISCUSSION}

The KOPIKu" application is an android-based application designed as a tool for family planning decisions. The KOPIKu" application contains information about contraceptive methods which are summarized in four menus, namely delaying pregnancy, spacing pregnancies, not getting pregnant, and postpartum contraception. Information contains how to use, side effects, etc..(Patimah, Kurniawati, \& Susilawati, 2020)

Knowledge is the result of knowing from humans, or the result of knowing someone about objects through the senses they have (eyes, nose, ears, and other senses). At the time of sensing to produce knowledge is strongly influenced by the intensity of understanding and perception of the object. Knowledge is strongly influenced by education, occupation, age, interests, experience, culture and information obtained. (Notoatmojo, 2015)

Knowledge is the result of remembering something, including recalling events that have been experienced either intentionally or unintentionally and this happens after people make contact or observation of a particular object. Knowledge is strongly influenced by education, occupation, age, interests, experience and information obtained. (Notoatmojo, 2015) 
The use of applications in smartphones effectively increases knowledge. (Kaewungwal et al., 2010) The increase in knowledge about IUD contraception in the application of the KOPIKu" application is quite high at $77.9 \%$. The use of the KOPIKu" application is very easy because this application is installed on mobile phones so that couples of childbearing age can access this information at any time even if they are offline. The use of language that is simple and easy to understand and the attractive appearance of this application makes it easier for couples of childbearing age to understand information.

\section{CONCLUSIONS AND SUGGESTIONS}

Community service by implementing the KOPIKu" application in Cilamajang Village. Kawalu District, Tasikmalaya City, the results showed that there was an increase in the knowledge of couples of childbearing age about the IUD contraceptive method.

The results of this community service are expected to be input for the Karanganyar health center to be able to take advantage of the KOPIKu" application as a medium of health education for couples of childbearing age. This result is also expected to be a reference for further community service.

\section{ACKNOWLEDGMENTS}

The authors thank the Chancellor and LPPM Muhammadiyah University of Tasikmalaya for the dedication funds. Thank you to the sub-district head of Kawalu sub-district, the head of the Karanganyar Health Center, the Lurah and the Cilamajang village midwife for their permission and support. And all those who have helped to carry out this service.

\section{REFERENCES}

BKKBN. (2019). Laporan Kinerja. Retrieved from https://www.bkkbn.go.id

Direktorat Bina Kesehatan Ibu Dirjen Bina Gizi dan Kesehatan RI. (2008). Factsheet Alat Bantu Pengambilan Keputusan-KB. Retrieved from www.dep.kes.go.id

FKUI. (2019). FKUI Siap Dukung Program Nasional Kependudukan dan Keluarga Berencana. Retrieved from FKUI website: http://uiupdate.ui.ac.id/article/fkui-siapdukung-program-nasional-kependudukan-dan-keluarga-berencana

Kaewungwal, J., Singhasivanon, P., Khamsiriwatchara, A., Sawang, S., Meankaew, W., \& Wechsart, A. (2010). Application of Smart Pone in "Better Border Health Care Program": A Module For Mother And Child Care. BMC, 10(69).

Lestari, J. P., Agushyana, F., \& Nugraheni, S. A. (2019). the Effect of Sik-Asiek Applications on Knowledge and Attitude for. 8(2), 108-115.

Notoatmojo. (2015). Pendidikan dan Perilaku Kesehatan. Jakarta: Rineka Cipta.

Patimah, M., Kurniawati, A., \& Susilawati, S. (2020). Application Design “KoPiKu Kontrasepsi Pilihanku" Of Mobile Contraception Making Tools Based On Android. Jurnal Kebidanan, 1, 1-8.

Patimah, M., Susilawati, S., Kurniawati, A., \& Tasikmalaya, U. M. (2020). KEPUASAN Pengguna KOPIKU “Kontrasepsi Pilihanku“ Aplikasi Kb Berbasis Android. Publikasi IImiah Nasional HUT IBI Ke 69. 


\section{ATTACHMENT}

Table 1 Frequency Distribution of Pregnant Women

\begin{tabular}{ccc}
\hline Usia & F & Persentase \\
\hline $21-25$ tahun & 6 & $17,1 \%$ \\
$26-30$ tahun & 16 & $45,7 \%$ \\
$31-35$ tahun & 8 & $22,9 \%$ \\
$>35$ tahun & 5 & $14,3 \%$ \\
\hline Jumlah & 35 & $100 \%$
\end{tabular}

Table 2 Distribution of the Education Frequency of Pregnant Women

\begin{tabular}{ccc}
\hline Pendidikan & F & Persentase \\
\hline SD & 4 & $11,4 \%$ \\
SMP & 9 & $25,7 \%$ \\
SMA & 22 & $62,9 \%$ \\
\hline Jumlah & 35 & $100 \%$ \\
\hline
\end{tabular}

Table 3 Distribution of Parity Frequency of Pregnant Women

\begin{tabular}{ccc}
\hline Paritas & F & Persentase \\
\hline Primigravida & 8 & $22,9 \%$ \\
Multigravida & 25 & $71,4 \%$ \\
Grandemultipara & 2 & $5,7 \%$ \\
\hline Jumlah & 35 & $100 \%$ \\
\hline
\end{tabular}

Table 4 Knowledge of Pregnant Women Before and After KOPIKu Application Application

\begin{tabular}{|c|c|c|c|c|}
\hline \multirow{2}{*}{ Kriteria } & \multicolumn{2}{|c|}{ Sebelum } & \multicolumn{2}{c|}{ Sesudah } \\
\cline { 2 - 5 } & Df & \% & Df & $\%$ \\
\hline Baik & 2 & 5,7 & 29 & 82,9 \\
\hline Cukup & 3 & 8,6 & 6 & 17,1 \\
\hline Kurang & 30 & 85,7 & 0 & 0 \\
\hline Jumlah & 35 & 100 & 35 & $100 \%$ \\
\hline
\end{tabular}




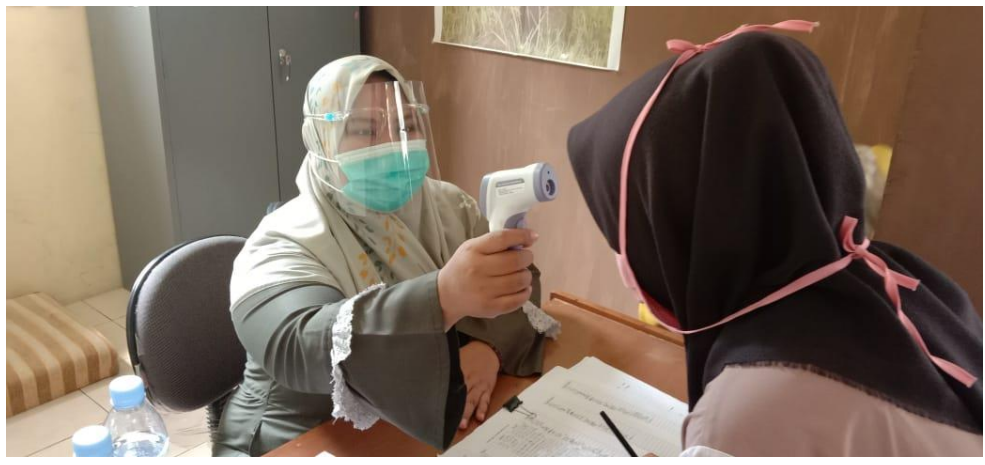

Sumber: dok kegiatan

Figure 1. Body Temperature Measurement

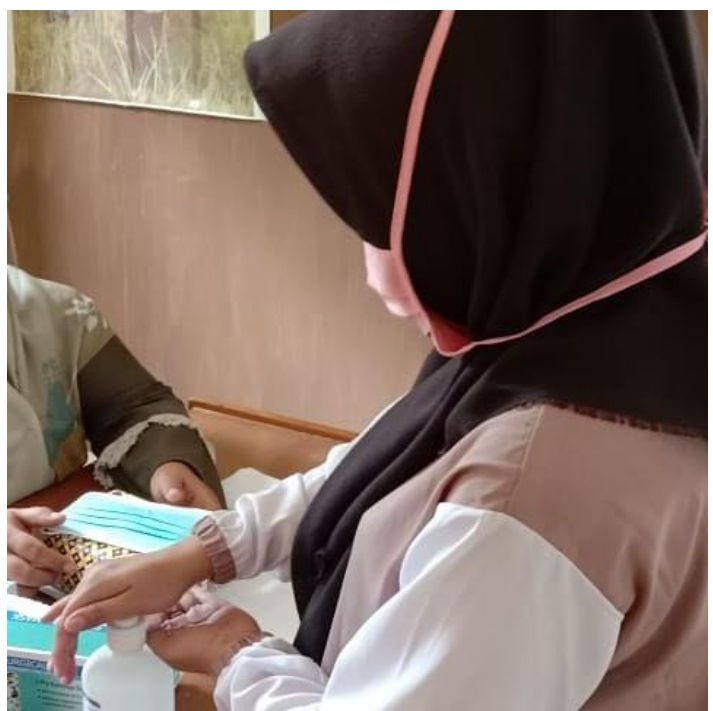

Sumber: dok kegiatan

Figure 2. Distribution of Masks and Use of Hand Sanitizer

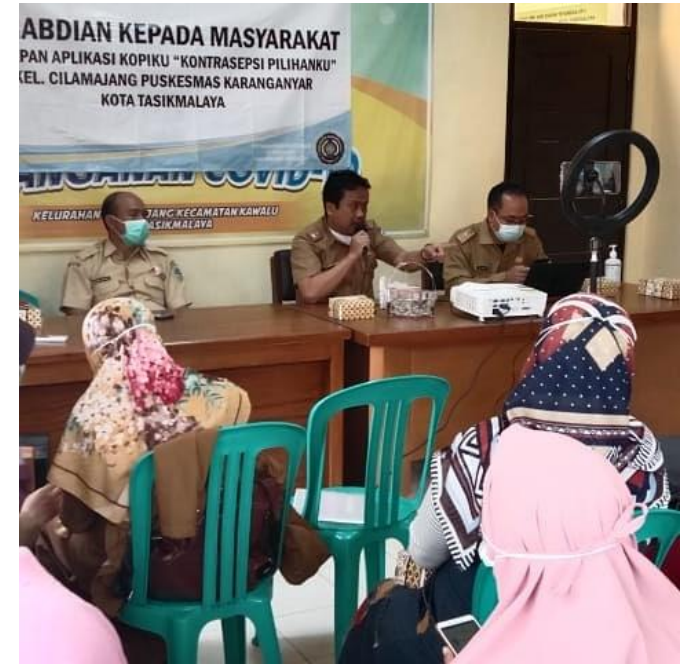

Source: activity dock

Figure 3. Opening and Briefing from the Camat, Lurah and Ka. Public health center 


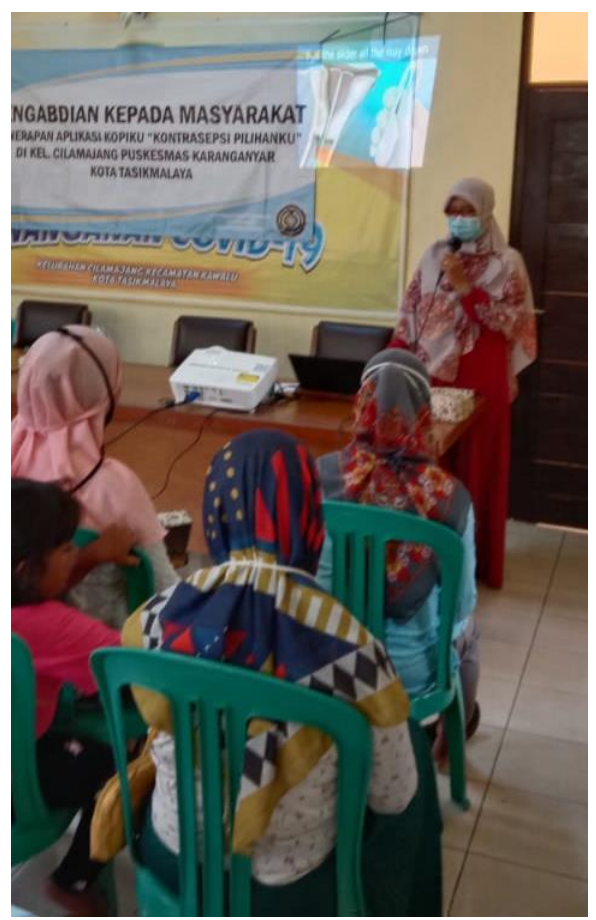

Source: activity dock

Figure 4. Explanation of Application Usage

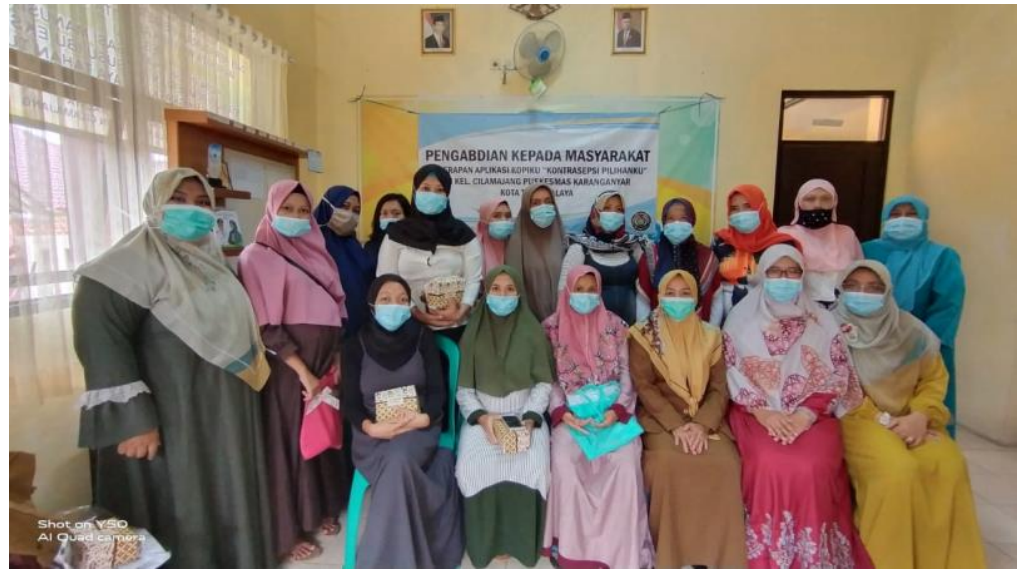

Source: activity dock

Figure 5. Service Participants 